\title{
Inventory Management and Financial Performance of Nepalese Public Enterprises
}

\author{
Nischal Risal \\ Lecturer, Nepal Commerce Campus, Tribhuvan University \\ Sangita Acharya \\ MBM Scholar, Nepal Commerce Campus, Tribhuvan University
}

\begin{abstract}
The objective of the research paper is to analyze the inventory management and the profitability of PE in Nepal. The descriptive and analytical research designs have been adopted in the study. The quantitative research approach has been used in the study. The population of the study is 37 public enterprises in Nepal. NFC, HPPC, and DDC are the samples taken based on purposive sampling method. The descriptive analysis, correlation analysis, and multiple regression analysis tools have been used in the study with seven years data from the years 2011AD to 2017AD. The variables used are $\mathrm{CR}, \mathrm{QR}, \mathrm{CCC}$, ITR, ROA, ROE, OM, firm growth, and size of the firm. The results provide the negative and insignificant relationship between inventory turnover and liquidity ratios with profitability. The results concluded the negative and insignificant relationship with current assets, quick assets with profitability. CCC is found as insignificant positive relationship with profitability. Thus, the study concluded that PE in Nepal should manage their working capital efficiently to achieve the optimal profitability even though the study found no significant
\end{abstract}


relationship of inventory management on the profitability of PEs in Nepal. The study highly recommend to not to ignore the inventory management by Nepalese public enterprises.

Keywords: Liquidity Ratio; Inventory Turnover; Growth Level; Size; Profitability

\section{Introduction}

In recent years, inventory management has become a great deal of attention from people globally. Proper management of inventory increases the profitability. The efficient and effective management of the inventories would release capital productivity. The viability of any business relies on managing the receivables, inventory, and payables effectively. Prudent management of inventory reduces depreciation, pilferage, and wastages while ensuring the availability of the materials as when required (Aje, 2009). Efficient management of working capital through proper inventory management ensures a balance between profitability and liquidity trade-offs (Aminu, 2012). When there is poor management of working capital; it reduces the liquidity and affects on profitability (Panigrahi, 2013). A negative relationship was established between inventory turnover, conversion period of inventory, and storage cost with profitability (Panigrahi, 2013). The high ITR could mean inventory level kept relatively low, it had indicated the loss of customers and profit declines significantly (Moridipour, 2014).The success or failure of a business dependson inventory management performances. The effective controls of inventories help in achieving better operational results. The inventory management is the overall strategic business plan in every organization (Sitienei, 2015). Inventory management is designed to capture the effectiveness of a company's management and profitability (Prempeh, 2015). Mwangi, (2016) concluded that less utilization of inventory and little knowledge of management to the business bring problems in the market demand. Most of the public manufacturing enterprises in Nepal are going through huge losses due to inefficient management of inventory. Every enterprise has to reconcile the conflicting objective of liquidity, and profitability in inventory management to obtain a higher return 
on investment and to maximize the value of the company in the market. In Nepal, PE is accepted to build the infrastructure to produce and supply important consumer goods in complement and supplement to the private sector and to operate as a model for efficiency. The growing number of corporations in Nepal is facing a problem of inventory management. Nepalese manufacturing companies are the victim of poor inventory management. The public manufacturing enterprises would be satisfied by eliminating the obstacles to be faced in the future. Inventory management is a wide subject but very few had paid serious attention in Nepalese context. The firms should embraced modern production technology that would enhance faster production to shorten inventory conversion period which would in turn improved inventory turnover and profitability (Sunday and Joseph, 2017). The modern techniques to manage inventories have been realized in the western world, in Nepal, many manufacturing corporations are still facing the problem of managing the physical and financial dimensions of inventories. Therefore, the study is aimed on the practices of inventory management in the public manufacturing enterprises in Nepal.

\section{Literature Review}

Lyroadi and Lazardis, (2000) did not found the relationship between CCC and leverage ratio. Capkun, (2009) had revealed the significant relationship between efficiency of working capital management and profitability. Rogers (2010) had concluded the inventory management as the major factor for the profitability in the manufacturing company. Panigrahi, (2013) had indicated an inverse relationship between inventory conversion period and profitability. Marobhe, (2014) and Altan, (2014) had found the working capital components relationship with profitability. Prempeh, (2015) had found that the raw material inventory management was designed to capture the effectiveness of a company's management on profitability. Mukopi, (2015) found that inventory management affected the performance of the procurement function of manufacturing companies. Ndirangukung'u, (2016) found that finance managers of manufacturing firms had taken precautions to ensure that firms maintained ideal levels of inventories of both raw materials and finished goods. Etale, (2016) found that efficient inventory cost management had 
positive effect on the profitability. Mwangi, (2016) had found inventory conversion period, management efficiency, and firm size negatively influenced the profitability. Margaretha, (2016) concluded that firm size, growth, lagged profitability, productivity, and industry affiliation influenced the profitability. Pokhrel andRisal (2016) revealed that most of the public trading enterprises and manufacturing enterprises were following aggressive working capital policy. Nepalese public trading enterprises and manufacturing enterprises were unable to maintain liquidity appropriately. Magar, (2016) revealed that CR, liquid ratio, loan and advance to deposit ratio, firm size, and financial leverage were the significant variables that affected the profitability. Pradhan, (2016) had revealed that CCC, credit risk, leverage, and bank age had impact on the profitability of Nepalese commercial banks. The inventory established an effective link between production and sales level, therefore become more critical for companies to effectively and efficiently manage their inventories (Etale, 2016). Profitability would be achieved at the optimum level of holding costs and ordering costs. Excessive inventories were the enemy of retail and wholesale profitability (Rahman, et al, 2016). Emmanuel, (2017) had evident that effective and efficient inventory management affected the profitability. Thirumagal, (2016) had explained CCC was the important measures of liquidity than the CR. Jain(2017) stated that the working capital played a vital role in the organization's operations, enhancing profitability and reducing the risk of insolvency. Bhandari, (2017) concluded the inventory management enabled avoidance of high investment in office supplies and other costs associated with inventory. The profitability in Jordanian trade companies was significantly influenced by liquidity (Al-Qadi, 2018). A liquidity creation increased the likelihood of bankruptcy, lowering bank profitability (Sahyouni, 2018). Siddiqui, (2019) found inventory control management had strong impact on the firm's performance and profitability that allowed strategic decisions to increase efficiency. Based on the reviewed literature, the conceptual framework has been developed. The CR, QR, CCC, ITR, GL and S have been taken as the independent variables. The ROA, ROE and OM have been taken as dependent variables in the study. 


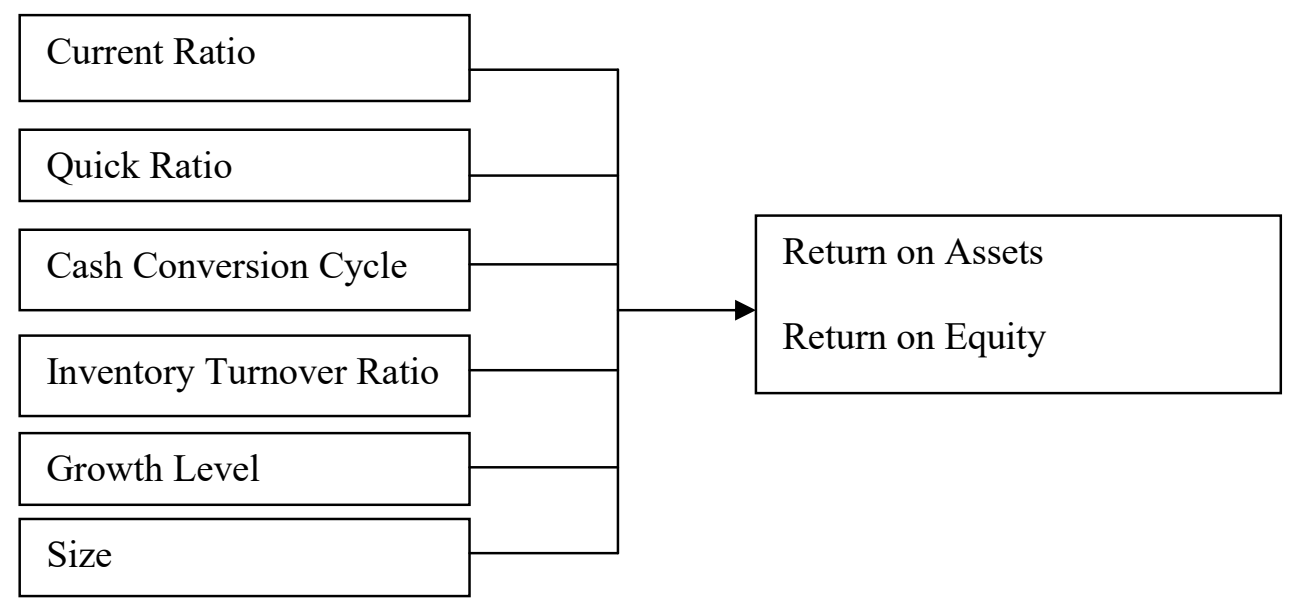

Figure 1: Conceptual Framework

\section{Research Methods}

The descriptive and analytical research designs had been adopted in the study. The quantitative research approach needed to quantify the data and calculated liquidity ratio, CCC, and ITR with the data obtained from the annual report of three public enterprises (PE) in Nepal. The population of the study comprised of public enterprises in Nepal. Among 37 operating PE, three enterprises had been taken as the sample under the purposive sampling method. The samples have been drawn with the notion that each enterprise had vintage of minimum 30 years of operation. The samples have been drawn each contributing in food, herbs and dairy products. The audited published reports have been other criteria for selecting the sample. The three enterprises were Nepal Food Corporation (NFC), Herbs Production and Processing Company (HPPC), and Dairy Development Corporation (DDC).All data have been entered in the SPSS software and analyzed. Data were presented and analyzed through statistical measures of central tendency, correlation, and regression analysis. ROA, ROE and OM were the major variables used in the reviewed literatures to measure the financial performance. The selected independent variables and its prior relationship with dependent variables were used in the study based on previous research papers findings. The expected sign has been shown in the model specifications. The study periods have been confined to $2011 \mathrm{AD}$ to $2017 \mathrm{AD}$. The current ratio, quick ratio, inventory turnover ratio have been expressed in terms of 
times, cash conversion cycle measures in terms of days, return on assets, return on equity and operating margin have been expressed in terms of percentages.

Models Specifications;

$$
\begin{aligned}
& R O A=\beta 0+\beta 1 C R+\beta 2 Q R+\beta 3 C C C+\beta 4 I T R+\beta 5 G L+\beta 6 S+e \\
& R O E=\beta 0+\beta 1 C R+\beta 2 Q R+\beta 3 C C C+\beta 4 I T R+\beta 5 G L+\beta 6 S+e \\
& O M=\beta 0+\beta 1 C R+\beta 2 Q R+\beta 3 C C C+\beta 4 I T R+\beta 5 G L+\beta 6 S+e
\end{aligned}
$$

Where,

$R O A=$ Return on Assets, $R O E=$ Return on Equity, $O M=$ Operating Margin, $C R=$ Current Ratio, $Q R=$ Quick Ratio, $C C C=$ Cash Conversion Cycle, ITR=Inventory Turnover Ratio, $G L=$ Growth Level, $S=$ Size of the Enterprise, $\beta_{0}=$ intercept and $\beta_{1}, \beta_{2}, \beta_{3}, \beta_{4}, \beta_{5}$ are the coefficient of the regression, $e=i$ s the error term.

\section{Results}

Descriptive Analysis

Table 1: Descriptive Statistics

\begin{tabular}{lllllll}
\hline Variables & Mean & & \multicolumn{5}{l}{ Std. Deviation } \\
\hline \multirow{2}{*}{ CR } & DDC & HPPC & NFC & DDC & HPPC & NFC \\
QR & 0.730 & 0.478 & 2.761 & 0.120 & 0.249 & 1.500 \\
CCC & 0.347 & 0.173 & 2.014 & 0.120 & 0.236 & 1.353 \\
ITR & 41.71 & 28.97 & 309.9 & 21.10 & 39.20 & 156.3 \\
ROA & 9.565 & 0.515 & 1.216 & 3.314 & 0.138 & 0.989 \\
ROE & -0.338 & -0.348 & 0.421 & 0.088 & 3.159 & 0.225 \\
OM & -0.590 & -0.535 & 0.257 & 0.156 & 3.049 & 0.043 \\
\hline
\end{tabular}

Table 1 had shown ROA and ROE on average indicated an insignificant return from the total assets invested.OM on average was found low as compared to ROA. On average liquidity position was fair. NFC had met the standard on liquidity indicated that NFC was able to manage its current assets and current liabilities compared to other two enterprises. On average the stock of DDC indicated a good efficiency of the management in production 
by the unit of sales. On average, PE were able to manage CCC on 41, 29 and 310 days respectively indicated that HPPC was able to control its current assets, liabilities, and ITR. Analysis of $C R$

Table 2: CR

\begin{tabular}{llll}
\hline Year & DDC & HPPC & NFC \\
\hline 2068 & 0.701 & 0.416 & 3.724 \\
2069 & 0.643 & 0.471 & 4.661 \\
2070 & 0.920 & 0.506 & 1.782 \\
2071 & 0.833 & 0.372 & 4.513 \\
2072 & 0.552 & 0.344 & 2.140 \\
2073 & 0.726 & 0.234 & 1.392 \\
2074 & 0.738 & 1.008 & 1.120 \\
Average & 0.730 & 0.478 & 2.761 \\
\hline
\end{tabular}

Table 2 had shown the CR of DDC, HPPC, and NFC. The position of CR of DDC and HPPC was found low, showing that these two enterprises were unable to meet the obligation of payback the short-term liability through the short-term assets. NFC maintained its short-term components well in comparison to the DDC and HPPC. The average CR of DDC and HPPC was below the theoretical standard value. CR of NFC had met the standard of CR. Hence, NFC had maintained its liquidity effectively. HPPC had little investment on current assets as compared to the other two enterprises.

Analysis of $Q R$

Table 3:QR

\begin{tabular}{llll}
\hline Year & DDC & HPPC & NFC \\
\hline 2068 & 0.382 & 0.157 & 1.945 \\
2069 & 0.361 & 0.229 & 3.697 \\
2070 & 0.292 & 0.276 & 1.461 \\
2071 & 0.519 & 0.153 & 4.099 \\
2072 & 0.277 & 0.137 & 1.335 \\
2073 & 0.450 & -0.268 & 0.826 \\
2074 & 0.153 & 0.528 & 0.739 \\
Average & 0.347 & 0.173 & 2.014 \\
\hline
\end{tabular}


Table 3 had shown that NFC QR met the general criteria, indicated that NFC had enough currents assets to meet the obligation. DDC and HPPC didn't meet the standard of QR but NFC had higher than the acceptable standard. QR had shown the extent of cash and other current assets that were readily convertible into cash in comparison to the short term obligations of the enterprises. It had indicated that the enterprises relied heavily on efficient inventory turnover to keep the float in short-term. A low ratio also caused concerned with potential investors and creditors because of short-term risks. It had indicated that NFC could easily handle the short-term obligation of the enterprise. On average, QR of NFC was acceptable but the QR of DDC, and HPPC had indicated an inadequate management of current assets, and current liabilities.

Analysis of CCC

Table 4:CCC

\begin{tabular}{llll}
\hline Year & DDC & HPPC & FC \\
\hline 2068 & 32.431 & 12.9 & 362.14 \\
2069 & 35.136 & 14.8 & 252.99 \\
2070 & 83.911 & 6.96 & 211.04 \\
2071 & 24.38 & 13.2 & 57.36 \\
2072 & 33.303 & 2.39 & 382.11 \\
2073 & 27.431 & 38.6 & 555.88 \\
2074 & 55.411 & 114 & 348.44 \\
Average & 41.714 & 28.97 & 309.99 \\
\hline
\end{tabular}

Table 4 had shown that CCC of DDC and HPPC was shorter whereas CCC of NFC was found longer indicating the chances of insolvency. Both DDC and HPPC had lower CCC which was good for the enterprises. NFC had a higher CCC, meaning NFC needed more cash for efficiency. It had indicated that the shorter $\mathrm{CCC}$, the more profitable the enterprises be. The notion had supported the theory. A shorter CCC indicated the greater liquidity of the enterprises, which translated into less need to borrow, more opportunities to realize price discounts with cash purchases for raw materials, and an increased capacity to fund the expansion of the business. 
Analysis of ITR

Table 5:ITR

\begin{tabular}{llll}
\hline Year & DDC & HPPC & FC \\
\hline 2068 & 10.311 & 0.46 & 0.96 \\
2069 & 9.411 & 0.38 & 0.89 \\
2070 & 4.173 & 0.40 & 1.05 \\
2071 & 13.56 & 0.42 & 3.43 \\
2072 & 10.43 & 0.57 & 0.74 \\
2073 & 12.64 & 0.63 & 0.57 \\
2074 & 6.42 & 0.75 & 0.85 \\
Average & 9.565 & 0.515 & 1.212 \\
\hline
\end{tabular}

Table 5 had shown that the ITR of DDC was higher than HPPC and FC. It had indicated the efficiency of the enterprises. Low ITR implied either poor sales or excess inventory. High ITR implied either strong sales or ineffective buying. It was evident that the enterprises could not afford to ignore ITR. While analyzing this ratio, the enterprises needed to keep a lot of factors in mind. A lower inventory ratio certainly needs to be improved. The analysis had indicated that HPPC and FC needed to pay more attention to better forecasting techniques. If these enterprises forecasted the demand of the customer correctly, they need to stock only those items that reduced inventory levels, which in turn would increase ITR. Analysis of ROA

Table 6:ROA

\begin{tabular}{llll}
\hline Year & DDC & HPPC & FC \\
\hline 2068 & -0.449 & -2.6 & 0.89 \\
2069 & -0.442 & -1.82 & 0.36 \\
2070 & -0.295 & -1.52 & 0.41 \\
2071 & -0.39 & -2.06 & 0.27 \\
2072 & -0.284 & -2.18 & 0.50 \\
2073 & -0.216 & 6.07 & 0.26 \\
2074 & -0.296 & 1.60 & 0.26 \\
Average & -0.338 & -0.358 & 0.421 \\
\hline
\end{tabular}


Table 6 shown NFC had positive but very low ROA. A high ROA indicated the business was able to utilize its resources well in generating income. Since the enterprises assets' sole purpose was to generate revenues and product profits, ROA had helped both management and investors to identify how well the company could convert its investments in assets into profits. A low percentage ROA had indicated that the company was not making enough returns from the use of its assets. All sampled enterprises were found in bad condition with respect to ROA. Lower returns could be acceptable but negative returns meant the corporations were not able to utilize their total assets properly.

Analysis of ROE

Table7:ROE

\begin{tabular}{llll}
\hline Year & DDC & HPPC & FC \\
\hline 2068 & -0.733 & -2.80 & 0.25 \\
2069 & -0.753 & -2.21 & 0.25 \\
2070 & -0.705 & -2.01 & 0.30 \\
2071 & -0.649 & -2.06 & 0.32 \\
2072 & -0.463 & -2.49 & 0.27 \\
2073 & -0.363 & 3.86 & 0.21 \\
2074 & -0.465 & 3.96 & 0.20 \\
Average & -0.590 & -0.535 & 0.257 \\
\hline
\end{tabular}

Table 7 had found negative ROE of DDC and HPPC. NFC had very low ROE. It had indicated that the high ROE might not always be positive and outsized ROE could be indicative several issues such as inconsistent profits or excessive debt. The negative ROE due to the company had net loss or negative shareholders' equity could not be used to analyze the enterprises' performance. By analyzing the ROE of DDC, HPPC and FC found that in the beginning of 2068 to the end of 2072, ROE was extremely low. In the year 2073 and 2074, ROE increased at low rate. Investors need high ROE ratio, indicated that the enterprises were using investor's funds effectively. Higher ratios were almost always better than lower ratios but had to be compared to other enterprise's ratios in the industry. 
Analysis of $O M$

Table 8:OM

\begin{tabular}{llll}
\hline Year & DDC & HPPC & NFC \\
\hline 2068 & 0.006 & -0.1 & -0.61 \\
2069 & 0.008 & -0.16 & -0.69 \\
2070 & 0.01 & -0.08 & -0.62 \\
2071 & -0.004 & -0.11 & -0.17 \\
2072 & 0.01 & -0.11 & -0.55 \\
2073 & 0.01 & -0.23 & -0.52 \\
2074 & 0.011 & -0.14 & -0.37 \\
Average & 0.007 & -0.132 & -0.504 \\
\hline
\end{tabular}

Table 8 had shown OM was very low and negative. It had indicated that when it comes to a negative OM, lower become well. Theoretically, higher the negative percentage, more severe was the operating loss. When the enterprises invested more money in daily operation as compared to its sales then the enterprises had to rely on cash reserves, money from selling assets, or money from new funding to pay operating costs. Because OM was measured before interest and taxes, the company also needed money to pay the nonoperating expenses. The analysis thus indicated that almost all enterprises were in negative $\mathrm{OM}$, which denoted that these three enterprises were not able to make sales as compared to operating cost. In all the observation periods HPPC and FC had negative OM but DDC had low positive $\mathrm{OM}$ in some observation years. The analysis indicated that the enterprises were experiencing a drop in sales or rises in costs.

Correlation Analysis

Table 9: Correlation Matrix

\begin{tabular}{llllllllll}
\hline & $\mathrm{CR}$ & $\mathrm{QR}$ & $\mathrm{CCC}$ & $\mathrm{ITR}$ & $\mathrm{ROA}$ & $\mathrm{ROE}$ & $\mathrm{OM}$ & $\mathrm{GL}$ & $\mathrm{S}$ \\
\hline $\mathrm{CR}$ & 1 & & & & & & & & \\
$\mathrm{QR}$ & $.952^{* *}$ & 1 & & & & & & & \\
& .001 & & & & & & & & \\
$\mathrm{CCC}$ & $-.775^{*}$ & $-.87^{* *}$ & 1 & & & & & & \\
& .041 & .010 & & & & & & & \\
\end{tabular}




\begin{tabular}{llllllllll}
\hline ITR & .406 & .448 & -.272 & 1 & & & & \\
& .366 & .313 & .555 & & & & & \\
ROA & -.665 & -.627 & $.769^{*}$ & .062 & 1 & & & \\
& .103 & .132 & .043 & .895 & & & & \\
ROE & -.654 & -.603 & .719 & -.063 & $.903^{* *}$ & 1 & & \\
& .111 & .152 & .069 & .893 & .005 & & & \\
OM & .161 & .297 & -.474 & .435 & -.156 & .077 & 1 & \\
& .730 & .518 & .282 & .329 & .739 & .869 & & \\
GL & .397 & .395 & -.594 & -.365 & $-.820^{*}$ & -.512 & .356 & 1 \\
& .378 & .381 & .160 & .421 & .024 & .240 & .433 & & \\
& .458 & .584 & -.617 & .548 & -.044 & -.004 & .736 & .055 & 1 \\
S & .450 & .168 & .140 & .203 & .926 & .992 & .060 & .908 \\
& .301 & & & & & & & & \\
\hline
\end{tabular}

Table 9 shown ROA and ROE had the negative relationship with CR and QR. The negative relation between profitability and liquidity ratio was consistent with the analysis that the current assets were low to payback their liability; the more the current assets were utilized in the enterprises increasing profitability. However, both profitability ratios and liquidity ratios had an insignificant effect on profitability. Further, the study established that firm size was positively related to ROA, ROE, and OM, indicated that larger firms reported higher returns on assets compared to smaller firms. This might be due to a larger firm's ability to exploit the economies of scale. Firm growth had positive relation to the dependent variable meaning as the sales of the firm grow there was higher likelihood that the firm recorded more profits unlike in case of declining sales. ITR on the other hand had the weak negative correlation coefficient with ROE. This implied that with increase in ROE, ITR would fall and vice versa though the relationship between them was statistically insignificant. CCC and OM had the weak negative relationship indicated that a decrease in the CCC lead to an increase in the OM and vice versa. The finding indicated that firms, which hold inventory for a longer period and payback its debt in short period, were likely to reduce their profits. 
Regression analysis with dependent variable ROA

$R O A$ of $D D C=-1.686-0.37 C R-0.95 Q R+0.018 C C C+0.126 I T R-0.054 G L+0.353 S+e$

$$
\begin{array}{cccccccc}
-2.799 & -0.658 & -1.489 & 2.142 & 2.368 & -0.226 & 0.899 \\
0.107 & 0.578 & 0.275 & 0.166 & 0.141 & 0.832 & 0.419 &
\end{array}
$$

$R=0.871 ; R$ Square: 0.758; Adjusted R Square: 0.274; SE of Estimate 0.075

$R O A$ of HPPC $=-8.31+0.819 C R-0.411 Q R-0.032 C C C+0.71 I T R-3.661 G L-8.250 S+e$

$$
\begin{array}{ccccc}
-1.267 & 1.520-2.450 & -0.4070 .010 & -3.922 & -0.917 \\
0.333 & 0.268 & 0.1340 .7240 .993 & 0.017 & 0.411
\end{array}
$$

$R=0.979 ; R$ Square: 0.959; Adjusted R Square: 0.878; SE of Estimate 1.104 $R O A$ of $N F C=-0.541+0.499 C R-0.616 Q R-0.001 C C C+0.015 I T R+0.233 G L-0.137 S+e$
2.658
$6.473-5.732$
$-2.171$
0.244
$0.315-0.893$
0.117
0.023
0.029
$0.162 \quad 0.830$
$0.769 \quad 0.422$

$R=0.979 ; R$ Square: 0.956; Adjusted R Square: 0.874; SE of Estimate 0.080

The R-value of $0.871,0.979$, and 0.979 indicated that there was a strong positive correlation between dependent variable (ROA) and the set of independent variables. The model $\mathrm{R}$ square value indicated that 75 percentages, 95 percentages, and 95 percentages of the variation in the dependent variable had been explained by the independent variables. It had indicated that the model was a strong predictor. The regression analysis had indicated that ROA would not depend on a constant factor $-1.686,-8.31$, and -0.541 respectively. Every unit increased of inventory turnover would increase ROA by $0.126,0.71, \& 0.014$ of DDC, HPPC and NFC respectively. On the other hand, liquidity ratios had negative relation with PE. Every unit increase in CCC affected profitability by $0.018,-0.032$, and -0.001 respectively. GL had negative and insignificant relationship with ROA. It had indicated that there was the indirect relationship of firms' growth with the profitability of PE.S had also negative and insignificant relationship with profitability.

Regression analysis with dependent variable $R O E$

ROE of DDC $=-2.4-0.198 C R-2.277 Q R+0.021 C C C+0.2 I T R-0.183 G L+0.005 S+e$

$$
\begin{array}{llllll}
-2.358 & -0.205 & -2.078 & 12.473 & 2.182 & -0.3990 .007 \\
0.142 & 0.857 & 0.173 & 0.279 & 0.161 & 0.7100 .995
\end{array}
$$


$R=0.878 ; R$ Square: 0.771; Adjusted R Square: 0.312; SE of Estimate 0.129 $R O E$ of HPPC $=-6.749+1.044 C R-1.348 Q R+0.02 C C C+1.278 I T R-2.575 G L-9.058 S+e$

$$
\begin{array}{ccccccc}
-1.2451 .051 & -1.732 & 0.305 & 0.228 & -1.677 & -0.612 \\
0.339 & 0.403 & 0.225 & 0.789 & 0.841 & 0.1690 .574
\end{array}
$$

$R=0.985 ; R$ Square: 0.970; Adjusted R Square: 0.910; SE of Estimate 0.913

$R O E$ of NFC $=0.31-0.01 C R-0.014 Q R+0.0 C C C+0.009 I T R+0.162 G L+0.018 S+e$

$$
\begin{array}{lllllll}
0.109 & 0.839 & 0.834 & 0.4490 .802 & 0.2350 .495 & \\
2.770 & 0.230 & -0.240 & -0.930 & 0.290 & 1.390 & 0.750
\end{array}
$$

$R=0.812$; $R$ Square: 0.659; Adjusted $R$ Square: -0.023; SE of Estimate: 0.044

The R-value $0.878,0.985$, and 0.812 indicated the strong correlation between the dependent and the independent variables. The model had $\mathrm{R}$ square value $0.771,0.97$, and 0.659 indicated that 77 percentages, 97 percentages and 66 percentages of the variation in the dependent variables had been explained by the independent variables in DDC, HPPC\& NFC respectively. The result on had shown that CR of DDC and NFC had the negative insignificant relationship with ROE.CR of HPPC had positive but insignificant relationship with ROE. CCC and ITR had the positive insignificant relationship with ROE. GL and S of enterprises had negative relation with ROE. The relationship was found statistically insignificant.

Regression analysis with dependent variable $O M$ OM of DDC $=0.016-0.039 C R-0.006 Q R+0.0 C C C+0.001 I T R+0.006 G L+0.0 S+e$

$$
\begin{array}{ccccccc}
0.388 & -1.041 & -0.132 & 0.625 & 0.2320 .370 & 0.510 \\
0.736 & 0.407 & 0.903 & 0.596 & 0.838 & 0.730 & 0.715
\end{array}
$$

$R=0.834 ; R$ Square: 0.695; Adjusted R Square: 0.085; SE of Estimate: 0.005 $O M$ of HPPC $=-0.198-0.13 C R+0.23 Q R-0.001 C C C+0.1361 T R+0.047 G L-0.126 S+e$

$$
\begin{array}{lllll}
-0.876 & -0.0200 .522-0.499 & 0.582 & 2.943-0.817 \\
0.473 & 0.9860 .653 & 0.667 & 0.619 & 0.0420 .460
\end{array}
$$

$R=0.900 ; R$ Square: 0.809; Adjusted $R$ Square: 0.428; SE of Estimate: 0.038 $O M$ of NFC $=-0.78-0.061 C R-0.006 Q R+0.0 C C C+0.243 I T R-0.3 G L+0.224 S+e$

$$
\begin{array}{lllllll}
-2.844 & -0.5830 .0400 .802 & 3.010 & -0.867 & 3.118 & \\
0.105 & 0.619 & 0.971 & 0.506 & 0.095 & 0.435 & 0.036
\end{array}
$$

$R=0.937 ; R$ Square: 0.878; Adjusted $R$ Square: 0.635; SE of Estimate: 0.101 
The R-value $0.834,0.90$, and 0.937 indicated the strong positive correlation between the dependent and the independent variables. The analysis had shown that the model $\mathrm{R}$ square of $0.695,0.809$, and 0.878 indicated that 69 percentages, 81 percentages and 87 percentages of the variation in the dependent variable was explained by the independent variables. The regression analysis had shown that $\mathrm{OM}$ had a negative relationship with $\mathrm{CR}$ and positive relation with ITR. While CCC did not affect on OM, the result showed that CR of DDC and NFC had a negative insignificant relationship with OM. CR of HPPC had positive but insignificant relationship with OM. ITR had a positive insignificant relationship with OM. GL and $\mathrm{S}$ of the enterprises had negative relation with OM. The relationship was statistically insignificant.

\section{Discussions and Conclusions}

NFC can manage its current assets and current liabilities compared to the other two enterprises. CR of DDC and HPPC showed the enterprises are unable to meet the obligation of payback the short-term liability through the short-term assets. NFC maintained its shortterm components in comparison to DDC and HPPC. Also, Both DDC and HPPC have lower CCC and NFC has higher CCC that means NFC needs more cash as it is on loss. ITR of DDC is high as compared to HPPC and NFC. It is evident that the companies cannot afford to ignore the ITR.ROA and ROE of DDC and HPPC are negative whereas NFC has positive but very low indicating that the company is not making enough income from the use of its assets. The study found a negative relation between liquidity ratios, $\mathrm{CCC}$ with ROA, ROE and OM which is reliable with the analysis that the lower the number of days the inventory is held in a firm before its turnover, the more the cash. The negative relation between profitability and liquidity ratio denotes that the current assets are low to payback its liabilities, the more the current assets are utilized in the firm increasing profitability. Further, firm size is positively related to ROA, ROE and OM, which means that larger firms report higher returns on assets compared to smaller firms. Firm growth has a positive relation to dependent variable meaning as the sales of the firm grow there is higher likelihood that the firm records more profits unlike in a case of declining sales. ITR has a weak negative correlation coefficient with ROE, which implies that with an increase in 
ROE, ITR would fall though the relationship between them is statistically insignificant. $\mathrm{CCC}$ and $\mathrm{OM}$ have a weak negative relationship mean that a decrease in the CCC leads to an increase in the OM. This finding indicates that firms, which hold inventory for a longer period and pay back its debt in short-period, are likely to reduce their profits. The results of the correlation analysis are consistent with earlier studies taken on this subject. The results so derived are also consistent with prior studies on these relationships. The study of inventory management in PE for the respective periods leads to the conclusion that inventory performance was satisfactory. Profitability is negatively correlated with the CCC. This means that by shortening ICP, and increasing PDP, firms' profitability improves. Improved coordination and control of the firm's stock will help the organization reduce unnecessary cost that would have reduced its revenues and at the same would improve over stocking and stock outs thus contributing overall efficiency of the firm. The study also concludes that increase in sales, which denotes the firm size enriches the firm's inventory levels, which pushes profits upwards due to optimal inventory levels. It is also noted that firms inventory systems must maintain an appropriate inventory levels to enhance profitability and reduce the inventory costs associated with holding excessive stock in the warehouses.

\section{Implications}

The managers of PEs are expected to consider inventory management practices as a one core enterprise objective to excel their competitiveness through making efficient management, quality product, meet market demand flexibly manner, and enhance their overall organizational performance. The further research can be undertaken to consider other factors which might influence organization's profitability such as performance of employees, holding cost, carrying cost, policies used by firms etc. PEs should manage their working capital efficiently to achieve the optimal profitability. These firms should maintain optimum current assets for their daily business processing as well as for meeting their short-term maturities otherwise profitability would be affected. PE in Nepal should adopt effective inventory management practices like material requirement planning. The management of PE in Nepal should develop effective strategic policies and guidelines on 
inventory management and current assets management. The management of PE in Nepal should focus on growing their enterprises since growing enterprises can grow their profitability, $\mathrm{OM}$ and increase their size.

\section{Acknowledgments}

The authors are highly indebted to the Master of Business Management (MBM) Program, Nepal Commerce Campus, Tribhuvan University as the research paper is based on the dissertation of MBM scholar. The inherent limitations of the data and results produced from the data analysis is solely depends on the secondary data availability and effort of the research scholar.

\section{References}

Aje, C. (2009). Effect of Inventory Management Practices on Financial Performance of Larfage Wapco Plc. Nigeria. European Journal of Business and Management, 9(8), 113-122.

Al-Qadi, N. S. (2018). Relationship Between Liquidity and Profitability: An Empericle Study of Trade Service Sector in Jordan. Research Journal of Finance and Accounting, 9(7), 153-157.

Altan, G. S. (2014). The Relationship between Inventory Management and Profitability: A Comparative Research on Turkish Firms Operated in Weaving Industry, Eatables Industry, Wholesale and Retail Industry. International Journal of Mechanical and Industrial Engineering, 8(6), 1698-1703.

Aminu, Y. (2012). Determinants of Inventory Management as a Component of Working Capital in Ensuring Corporate Profitability- A Conceptual Approach. 3(11), 5861.

Bhandari, H. B. (2017, December). Factors Affecting the Efficiency of Inventory Management of Janapriya Multiplus Campus, Pokhara. Janapriya Journal of Interdisciplinary Studies, 6, 78-87.

Emmanuel, M. (2017). The Impact of Inventory Management on Profitability: A Case of Distribution and Wholesale Firms in Ghana. Asian Journal of Economics, Business and Accounting, 2, 2-11. 
Etale, L. (2016). The Effect of Iiventory Cost Management on Profitability: A Study of Listed Brewery Companies in Nigeria. International Journal of Economics, Commerce and Management, 4(6), 446-455.

Lyroadi, and Lazadis, (2000). Short term financial management of business increases and in Cyprus. Business and Economic society international.

Magar, G. T. (2016, OCTOBER). Liquidity management and bank profitability: A case of Nepalese commercial banks. Nepalese Journal of Management, 3(4), 55-70.

Margaretha, F. (2016). Factors Affecting Profitability of Small Medium Enterprises (SMEs) Firm Listed in Indonesia Stock Exchange. Journal of Economics, Business and Management, 4, 132-137. doi: 10.7763

Marobhe, M. I. (2014). An Empirical Analysis of the Relationship between Working Capital Management and Profitability: Panel Evidence from Listed Manufacturing Companies in East Africa. European Journal of Business and Management, 6, 212-219.

Moridipour, H. (2014). Relationship between inventory turnover with gross profit margin and sales shocks. International Research Journal of Applied and Basic Sciences, 8(8), 1106-1109.

Mukopi, C. M. (2015). An Analysis of the Effects of Inventory Management on the Performance of the Procurement Function of Sugar Manufacturing Companies in the western Kenya Sugar Belt. International Journal of Scientific and Research Publications, 5(5), 1-13.

Mwangi, L. (2016). The Effect of Inventory Management on Firm Profitability and Operating Cash Flows of Kenya Breweries Limited, Beer DistributionFirms in Nairobi Country. University of Nairobi,1-61.

Ndirangukungu, J. (2016). Effects of Inventory Control on Profitability of Industrial and Allied Firms in Kenya. IOSR Journal of Economics and finance, 7(6), 9-15.

Panigrahi, D. A. (2013). Relationship between inventory management and profitability: An empirical analysis of Indian cement companies. Asia Pacific Journal of Marketing \& Management Review, 2 (7), 107-120.

Pokhrel, B.B., and Risal, N. (2016). Analysis of Short Term Financial Liquidity Position of Public Manufacturing and Trading Enterprises: Empirical Evidence from Nepal. Journal of Indian Research, 4, 101-116. 
Pradhan, S. (2016). Impact of working capital management on banks profitability: case of Nepalese Commercial Banks. Nepalese Journal of Management, 4(3), 171-185.

Prempeh, K. B. (2015). The impact of efficient inventory management on profitability: evidence from selected manufacturing firms in Ghana. Munich Personal, 1-6.

Rahman, Et al. (2016). A Study on Relationship between Inventory Management and Company Performance: A Case Study of Textile Chain Store. Journal of Advance Management Science, 299-304. doi:10.12720

Rogers, M. M. (2010, November). The Relationship between Inventory Management and Firm Profitability: Sector Consequences of Catastrophic Supply Chain Disruption. California Journal of Operations Management, 8(2), 39-54.

Sahyouni, A. \&. (2018). The determinants of Bank Profitability: Does Liquidity Creation Matter? Journal of Economic and Financial Analysis, 2(2), 61-85.

Siddiqui, K. F. (2019). Impact of Inventory Management on Firm's Efficiency - A Quantitative Research Study on Departmental Stores Operating in Karachi. Social Science and Humanities Journal, 03(04), 964-980.

Sitienei, E., M. F. (2015). The Effect of Inventory Management on Profitability of

Cement Manufacturing Companies in Kenya: A Case Study of Listed Cement Manufacturing Companies in Kenya. International Journal of Management and Commerce Innovations, 3, 111-119. Retrieved from www.researchpublish.com

Sunday, O., \& Joseph, E.E. (2017). Inventory Management and SMEs Profitability: A Study of Furniture Manufacturing, Wholesale and Eatery Industry in Delta State, Nigeria. Journal of Finance and Accounting, 5 (3), 75-89, doi: 10.12691/jfa-5-3-1

Thirumagal, D. S. (2016). Impact of Working Capital on the Profitability of the Company. Global Journal of Engineering Science and Research Management, 3(5), 117125. Retrieved from; http: // www.gjesrm.com 